\title{
II ruolo della vittima davanti alla Corte Penale Internazionale: dal diritto al processo al diritto nel processo e al di là del processo
}

\author{
O papel da vítima perante o Tribunal Penal Internacional: do direito ao processo \\ ao direto no processo e além do processo
}

\section{The role of the victim before the International Criminal Court: from the right to the process to the right in the process and beyond the process}

Agostina Latino

\begin{abstract}
II 17 luglio 1998, durante i negoziati a Roma, 120 Stati hanno deciso di istituire una Corte Penale Internazionale permanente. Per la prima volta nella storia della giustizia penale internazionale, i negoziatori dello Statuto di Roma hanno posto le vittime al centro del processo, riconoscendo fin dal secondo paragrafo del preambolo che gli Stati parti erano "consapevoli che durante [l'ultimo] secolo milioni di bambini, donne e uomini sono stati vittime di atrocità inimmaginabili che hanno profondamente scosso la coscienza dell'umanità". Lo Statuto di Roma consente alle vittime di crimini che rientrano nella competenza ratione materiae della Corte di essere rappresentate, di presentare osservazioni e che le loro opinioni e istanze siano tenute in considerazione, quando i loro interessi personali siano coinvolti, in tutte le fasi del procedimento, oltre a poter chiedere riparazioni per il danno subito. Di tal guisa, secondo lo Statuto di Roma, le vittime sono attori della giustizia internazionale piuttosto che meri soggetti passivi. In questo articolo, si esaminerà il ruolo delle vittime nel sistema della Corte penale internazionale, i diritti contemplati nello Statuto e negli altri regolamenti che disciplinano i procedimenti della Corte, nonché le interpretazioni che ne ha dato la Corte nelle sue prime pronunce.
\end{abstract}

Parole Chiave: Corte Penale Internazionale. Vittime di crimini. Diritto alla partecipazione. Diritto alla protezione. Diritto a riparazioni.

\section{Resumo}

Em 17 de julho de 1998, durante as negociações em Roma, 120 Estados decidiram criar um Tribunal Penal Internacional permanente. Pela primeira vez na história da justiça penal internacional, os negociadores do Estatuto de Roma colocaram as vítimas no centro do processo, reconhecendo, a partir do segundo parágrafo do preâmbulo, que os Estados Partes estavam "conscientes de que, durante o último século, milhões de crianças, mulheres e homens foram vítimas de atrocidades inimagináveis que abalaram profundamente a consciência da humanidade". O Estatuto de Roma permite que as vítimas de crimes que se enquadram na competência ratione materiae do Tribunal sejam representadas, apresentem observações e que as suas opiniões e petições sejam tidas em consideração quando os seus interesses pessoais estejam envolvidos, em todas as etapas do processo, além de poder solicitar reparações pelos danos sofridos. Desta forma, de acordo com o Estatuto de Roma, as vítimas são atores da justiça internacional, em vez de meros sujeitos passivos. Neste artigo, examinaremos o papel das vítimas no sistema do Tribunal Penal Internacional, os direitos estabelecidos no Estatuto e os demais regulamentos que regem os procedimentos do Tribunal, bem como as interpretações que o Tribunal de Justiça pronunciou nas suas primeiras decisões.

Palavras-Chave: Tribunal Penal Internacional. Vítimas de crimes internacionais. Direito à participação. Direito à proteção. Direito à reparação. 


\section{Abstract}

On July 17 1998, during the negotiations in Rome, 120 States decided to establish a permanent International Criminal Court. For the first time in the international criminal justice history, the negotiators of the Rome Statute placed the victims at the center of the process, recognizing, from the second paragraph of the preamble, that States Parties were "aware that over the last century millions of children, women and men were victims of unimaginable atrocities that profoundly shook the conscience of humanity". The Rome Statute allows victims of crimes falling within the jurisdiction ratione materiae of the Court to be represented, to submit observations and to have their views and petitions taken into account, when their personal interests are involved, at all stages of the process, in addition to being able to request repairs for the damages suffered. Thus, according to the Rome Statute, victims are actors in international justice rather than mere taxable persons. In this article, the role of victims in the International Criminal Court system, the rights set out in the Statute and the other regulations governing the Court's proceedings are examined, as well as the interpretations that the Court of Justice delivered in its first decisions.

Keywords: International Criminal Court. Victims of international crimes. Right to participation. Right to protection. Right to reparation.

\section{Introduzione}

I primi processi penali internazionali per crimini di guerra e contro l'umanità sono stati quelli, celeberrimi, del Tribunale Militare Internazionale di Norimberga ${ }^{1}$ e Tribunale Militare Internazionale per l'Estremo Oriente di Tokyo. ${ }^{2}$ In quei procedimenti le vittime non godevano di alcuno status particolare: non era loro riconosciuta la possibilità di costituirsi parte civile, né era prevista alcuna regolamentazione di un diritto a compensazione o risarcimento danni, né tampoco era contemplato un organo specifico che si occupasse della tutela dei loro interessi. Detto in altri termini, il problema del ruolo delle vittime nel processo era stato risolto - più o meno consapevolmente - in modo draconiano: negare in toto la questione della loro partecipazione. Questa scelta probabilmente sottintendeva l'idea che il soddisfacimento degli interessi delle vittime dovesse identificarsi con la circostanza stessa che, per la prima volta nella storia, fossero celebrati processi internazionali per crimini di questa natura e portata. Per quel che concerne la posizione giuridica delle vittime di crimini internazionali, la creazione della Corte Penale Internazionale (CPI) ${ }^{3}$ rappresenta un punto di snodo rispetto alle precedenti generazioni di istanze giurisdizionali internazionali, perché sembra abbandonare l'ottica strettamente retributivista dei Tribunali militari del '45/'46, condivisa, in parte, dai Tribunali ad hoc per la ex-lugoslavia ${ }^{4}$ e del Ruanda 5 focalizzati esclusivamente sul profilo della punizione e repressione dell'autore del crimine $^{6}$ : lo Statuto della CPI assegna un ruolo di primo piano alle vittime,

Creato sulla base della Carta di Londra dell'8 agosto 1945 dalle quattro cd Grandi Potenze (Usa, Unione Sovietica, Regno Unito, Francia), risultate vincitrici nel Secondo Conflitto Mondiale.

Creato il 19 gennaio 1946 con un special proclamation order del Generale statunitense Douglas MacHartur, con cui venne altresì adottata la Charter of the International Military Tribunal for the Far East che riecheggiava largamente la Carta di Londra.

Lo Statuto di Roma che ha dato vita alla CPI è stato adottato il 17 luglio 1998 ed è entrato in vigore il $1^{\circ}$ luglio 2002 in esito al deposito del sessantesimo strumento di ratifica, secondo quanto disposto dall'art. 126 dello Statuto. Benché a oggi gli Stati parte siano 123 , ossia quasi i due terzi dei membri delle Nazioni unite (NU), non va dimenticato che alcune delle maggiori potenze mondiali, tra cui ben tre membri permanenti del Consiglio di Sicurezza (USA, Federazione Russa e Cina), rifiutino a tutt'oggi di partecipare al sistema della CPI. Per la situazione aggiornata delle ratifiche si veda il sito: https://asp.icc-cpi.int/en_menus/asp/states\%20parties/Pages/the\%20states $\% 20$ parties $\% 20$ to\%20the $\% 20$ rome\%20statute. aspx. Accesso en: 12 dez. 2017

4 International Criminal Tribunal for the former Yugoslavia (ICTY), istituito il 25 maggio 1993 con la Risoluzione S/RES/827 del Consiglio di sicurezza (Cs) dell'Organizzazione delle Nazioni Unite (ONU) nella quale, giova ricordare, si afferma che l'ICTCY è creato "for the sole purpose of prosecuting persons responsible for serious violations of international law", senza alcuna menzione per le vittime.

International Criminal Tribunal for Rwanda (ICTR), istituito l'8 novembre 1994 con la Risoluzione S/RES/955 del Cs dell'ONU.

6 In verità gli Statuti dei due Tribunali ad hoc prevedono alcune disposizioni innovative, quali ad esempio procedure speciali di protezione (l'art. 22 dello Statuto ICTY, successivamente agli emendamenti del 17 maggio 2002, e alcune Regole di Procedura e Prova, post emendamenti del 29 maggio 2013, quali Rule 69: Protection of Victims and Witnesses, 75: Measures for the Protection of Victims and Witnesses, 79: Closed Sessions) e la creazione di una sezione Victims and Witnesses Section, ex Rule 34 emendata, finalizzata ad adottare raccomandazioni in tema di protezione e di assistenza amministrativa delle vittime, che presuppongono quindi di fatto che le vittime si siano recate "fisicamente" dinanzi ai Tribunali ad hoc, in veste di testimoni. Precedentemente agli emendamenti l'unico potere dei giudici de L'Aia e di Arusha rispetto alla riparazione per le vittime, previsto rispettivamente dagli artt. 24.3 Statuto ICTY e 23.3 Statuto ICTR, era quello di ordinare la restituzione di proprietà di cui i legittimi titolari fossero stati privati per effetto della commissione del crimine. Sorprendentemente, tale potere non risulta mai essere stato esercitato dai Tribunali ad hoc. 
riconoscendo loro un insieme di poteri processuali e diritti sostanziali senza precedenti nella storia del diritto penale internazionale (in generale, sul tema, si veda LATTANZI, 2010, p. 124 ss.).

Nel presente contributo si cercherà di dar conto di questa evoluzione: dopo aver individuato la nozione di vittima si analizzerà la ratio del coinvolgimento delle vittime nel processo davanti alla CPI, del loro diritto alla partecipazione al procedimento e delle articolazioni del sistema riparatorio, alla luce delle sentenze della Corte, per concludere infine con alcune osservazioni critiche.

\section{La nozione di vittima}

Tradizionalmente il diritto alla riparazione del pregiudizio derivante da illeciti internazionali è stato inquadrato nella prospettiva dei rapporti interstatali, ossia nella fattispecie di illeciti perpetrati da Stati a danno di altri Stati. Basti pensare che anche l'istituto della protezione diplomatica, è declinato in chiave interstatale: è il Paese di cittadinanza dell'individuo (leso nei suoi diritti da uno Stato diverso dal proprio) che può (non deve...) avanzare pretese risarcitorie sul piano internazionale. Ė di tutta evidenza quindi come in questo àmbito il rilievo ordinamentale della persona umana sia pressoché nullo. Questa impostazione era ben cristallizzata nel pensiero degli studiosi "classici" come per esempio Dionisio Anzilotti (1906, p. 5), per il quale "la conduite d'un Etat, toute contraire qu'elle soit au droit internationale ne saurait jamais donner naissance à un droit de l'individu a la réparation du dommage souffert". Paradossalmente l'assenza di qualsiasi ruolo per le vittime nel sistema di giustizia penale internazionale, al netto di quello eventuale di testimone, oltre a essere motivo di frustrazione, ha comportato una sorta di vittimizzazione secondaria, ossia una post-crime victimization (BARIL et al., 1985, passim; DEL PILAR MARTíN RÍOS, 2012, p. 437 ss.; WEMMERS, 2012, p. 72 ss.).

II mutamento di paradigma si registra solamente in tempi recenti a fronte della progressiva convergenza di tre settori del diritto internazionale (diritto internazionale umanitario, ${ }^{7}$ diritto internazionale dei diritti della persona umana ${ }^{8}$ e diritto penale internazionale) che ha generato una tendenza alla considerazione dell'individuo come centro d'imputazione di diritti, doveri e divieti, rispettivamente riconosciuti e imposti da norme internazionali (MCCARTHY, 2012, p. 36 ss.).

A livello normativo, il tema della riparazione ha avuto un suo primo inquadramento generale nei Basic Principles and Guidelines on the Right to a Remedy and Reparation for Victims of Gross Violations of International Human Rights Law and Serious Violations of International Humanitarian Law Victims (cd. Basic Principles). Benchè mero strumento di soft law, i Basic Principles possono essere considerati una sorta di bill of rights delle vittime (BASSIOUNI, 2006, p. 208), definite nella risoluzione come

\footnotetext{
L'articolo 91 del Primo Protocollo Addizionale alle Convenzioni di Ginevra del 1977, che ricalca pressoché del pari la disposizione di cui all'articolo 3 della IV Convenzione dell'Aia del 1907, recita: "A belligerent party which violates the provisions of the said Regulations shall, if the case demands, be liable to pay compensation". Benché si tratti di una disposizione volta a stabilire una responsabilità da inquadrarsi nei rapporti interstatali, limitata peraltro a una compensazione monetaria, si registrano in dottrina tentativi di reinterpretarla in chiave individuale, riconoscendole il ruolo di base giuridica per il diritto della vittima alla riparazione nei casi di violazione di norme di jus in bello: Kalshoven (1991, p. 830); Greenwood (2000, p. 250); Zegveld (2003, p. 501 ss.); Perrakis (2017, p. 283).

8 È ovviamente impossibile in queste brevi note dar conto in maniera esaustiva dei trattati in tema di diritti della persona umana, tanto universali quanto regionali, che prevedono sia un diritto della vittima, nel caso di violazione di un proprio diritto fondamentale, a un effective remedy (previsto fin dal Patto internazionale sui diritti civili e politici del 1966, ex art.2.3.a: "Any person whose rights or freedoms as herein recognized are violated shall have an effective remedy"), sia la possibilità di rivolgersi a istanze di supervisione, create ad hoc, dotate non solamente dell'autorità di interpretare e applicare documenti vincolanti posti a tutela dei diritti fondamentali, ma anche capaci di ricevere petizioni individuali onde, se del caso, raccomandare una riparazione. Ex plurimis si fa riferimento all'art. 6 della Convenzione per l'eliminazione di ogni forma di discriminazione razziale del 1965; all'art. 14 della la Convenzione contro la Tortura del 1984; all'art. 39 della Convenzione sui diritti del fanciullo del 1989, all'art. 24.4 della Convenzione per la protezione di tutte le persone dalla sparizione forzata del 2006. Questa prassi è posta a suffragio dell'art. 33.2 del Draft articles on Responsibility of States for Internationally Wrongful Acts, redatto dalla Commissione del diritto internazionale (2001), ossia della clausola di compatibilità di un doppio regime di responsabilità (dello Stato nei confronti di altri Stati e di responsabilità e obblighi nei confronti di singoli individui) in virtù della quale "[...] This part (i.e. Content of international responsibility of a State) is without prejudice to any right, arising from the international responsibility of a State, which may accrue directly to any person or entity other than a State". Sul piano regionale in tema del diritto della vittima a ottenere ristoro del pregiudizio subito in esito a violazioni di diritti fondamentali sono estremamente rilevanti l'effetto trainante della prassi della Corte di Strasburgo, nel quadro della Convenzione europea per la salvaguardia dei diritti dell'uomo e delle libertà fondamentali del 1950, e il contributo pioneristico e all'avanguardia della Corte di San Josè, nell'àmbito della Convenzione americana sui diritti umani del 1969.
} 
[...] persons who individually or collectively suffered harm, including physical or mental injury, emotional suffering, economic loss or substantial impairment of their fundamental rights, through acts or omissions that constitute gross violations of international human rights law, or serious violations of international humanitarian law. Where appropriate, and in accordance with domestic law, the term 'victim' also includes the immediate family or dependants of the direct victim and persons who have suffered harm in intervening to assist victims in distress or to prevent victimization. ${ }^{9}$

In tale Risoluzione, che peraltro fa riferimento alla vittima secondo "il sistema penale di uno Stato" e non si occupa quindi delle vittime dei crimini di rilevanza internazionale, si accoglie una nozione di vittima omnicomprensiva: individuale o collettiva, diretta o indiretta - sono tali i familiari della vittima diretta, chi dipende dalla vittima diretta o chi è stato leso nei propri diritti essendo intervenuto per assistere la vittima diretta o per prevenire la commissione dell'illecito -, che abbia patito un pregiudizio inter alia fisico, mentale, emotivo, economico ovvero la menomazione significativa dei propri diritti fondamentali.

Vero è che i Basic Principles sono stati adottati successivamente alla formulazione dello Statuto di Roma ma in verità la contaminazione reciproca è evidente sia alla luce di talune definizioni, ${ }^{10}$ sia nei frequenti richiami nei considerando del Preambolo, sia - soprattutto - nella prassi applicativa della CPI che indica i Basic Principles quali useful guidance. ${ }^{11}$

Nell'articolato sistema della CPI la definizione di vittima si rinviene nella Rule 85 del Regolamento di Procedura e Prova (Rules of Procedure and Evidence - RPE) ai sensi della quale:

(a) 'Victims' means natural persons who have suffered harm as a result of the commission of any crime within the jurisdiction of the Court;

(b) Victims may include organizations or institutions that have sustained direct harm to any of their property which is dedicated to religion, education, art or science or charitable purposes, and to their historic monuments, hospitals and other places and objects for humanitarian purposes.

Al fine di poter chiarire alcuni dubbi ermeneutici, la nozione di vittima contemplata nella Rule 85 va letta in combinato disposto con l'art. 75.2 dello Statuto, ai sensi del quale la Corte "[...] may make an order directly against a convicted person specifying appropriate reparations to, or in respect of, victims [...]". ${ }^{12}$ Da ciò si desume che il novero delle vittime ricomprende anche quelle indirette e/o mediate, includendo quindi i membri della famiglia e i successori delle vittime dirette, coloro che hanno tentato di impedire la commissione del crimine e quelli danneggiati per il loro aver prestato aiuto e soccorso alle vittime dirette, ${ }^{13}$

9 Assemblea generale delle NU, Basic Principles and Guidelines on the Right to a Remedy and Reparation for Victims of Gross Violations of International Human Rights Law and Serious Violations of International Humanitarian Law: Resolution adopted by the General Assembly, 21 March 2006, A/RES/60/147, in specie par. 8. Già precedentemente, nel 1985, l'Assemblea generale delle NU aveva adottatto la Declaration of the Basic Principles of Justice for Victims of Crime and Abuse of Power, con la Risoluzione A/RES/4034. Ai sensi del par. 1 di tali UN Principles per vittime si intendono "[...] persons who, individually or collectively, have suffered harm, including physical or mental injury, emotional suffering, economic loss or substantial impairment of their fundamental rights, through acts or omissions that are in violation of criminal laws operative within member States, including those laws proscribing criminal abuse of power". II corsivo è aggiunto per enfatizzare come nella Risoluzione non ci si occupasse in verità delle vittime dei crimini di rilevanza internazionale.

10 Basti pensare al fatto che la nozione di vittima non è direttamente stabilita nello Statuto della CPI, ma una nota all'art. 68 (contenuta nel Rapporto del Comitato di redazione dello Statuto) chiarisce che "in the exercise of its powers under this article, the Court shall take into consideration the United Nations Declaration of Basic Principles of Justice for Victims of Crime and Abuse of Power".

11 Da ultimo si veda il documento Victims' Views and Concerns on the Issue of Reparation or Assistance in Lieu of Reparation Pursuant to the Trial Chamber Decision of 5 April 2016 on the Defence Motions on 'No Case to Answer' (Legal Representatives of Victims, Submission), nel caso The Prosecutor v. William Samoei Ruto and Joshua Arap Sang, ICC-01/09-01/11-2035, 15 June 2016.

12 La versione francese, lingua ufficiale dello Statuto al pari dell'inglese, recita che la Corte "peut rendre contre une personne condamnée une ordonnance indiquant la réparation qu'il convient d'accorder aux victimes ou à leurs ayants droit', laddove, curiosamente, la versione spagnola, idioma in cui ugualmente lo Statuto fa fede, si limita ad affermare che "La Corte podrá dictar directamente una decisión contra el condenado en la que indique la reparación adecuada que ha de otorgarse a las víctimas".

13 Dalla prassi della CPI si evince peraltro che il danno rilevante deve promanare dal crimine di cui l'imputato si trova a rispondere: nel caso Lubanga i bambini soldato sono stati considerati vittime dirette dell'illecito contestato a Lubanga, ma i soggetti passivi delle azioni criminose a loro volta poste in essere dai bambini soldato sono stati esclusi dal novero delle vittime indirette per mancanza di una "stretta relazione personale": ICC Lubanga Dyilo ICC-01/04-01/06-1813 Redacted Version of Decision on 'Indirect Victims', Trial Chamber 8 aprile 2009, parr. 45, 50, 52. II nesso tra vittima diretta e vittima indiretta è, per così dire, bilaterale (non sono ammessi ulteriori gradi "a cascata") sicché nel caso Lubanga lo status di vittima indiretta è stato riconosciuto ai genitori dei bambini soldato, in ragione del pregiudizio psicologico-economico risultante dalla perdita del figlio arruolato forzatamente, nonché al direttore di un istituto scolastico che aveva cercato di opporsi al reclutamento dei suoi allievi nelle truppe di Lubanga. Peraltro la scuola stessa è stata ammessa come parte civile: ICC Lubanga Dyilo ICC-01/04-01/06-1556-Corr. Decision on the Applications by Victims to Partecipate in the Proceedings, Trial Chamber, 15 dicembre 2008, parr. 105-111. (AMATI et al. 2016, p. 298). Sul caso Lubanga alla luce della restorative justice si veda Ochi, 2016. 
a differenza di quanto previsto nei Tribunali ad hoc. ${ }^{14}$ Tale esegesi è confermata peraltro dalla prassi della CPI. ${ }^{15}$

Va rilevato, ancora, ex Rule 85.b, il pregevole e pioneristico ricomprendere nel novero delle vittime enti giuridici che abbiano subìto danni su propri beni che siano strumentalmente destinati alle attività culturali, religiose, educative, artistiche scientifiche e caritatevoli ${ }^{16}$ : questa inclusione, la cui base giuridica si rinviene nei crimini di competenza della Corte che riguardano il patrimonio artistico e i beni di rilievo storico-culturale, si basa sulla triste esperienza dei Tribunali ad hoc che ha evidenziato come spesso il crimine internazionale possa colpire, anche in modo sistematico, i beni culturali pertinenti a determinate comunità sociali. Di tal guisa, nella sentenza del settembre 2016 relativa al caso The Prosecutor v. Ahmad Al Faqi Al Mahdi, la CPI ha stabilito che la distruzione delle tombe sufi, delle porte della moschea di Sidi Yahia e l'incendio della biblioteca di Timbuctu perpetrati nell'estate del 2012 dal gruppo Ansar Dine sono crimini di guerra, condannando a nove anni di reclusione il cittadino maliano Ahmad Al Mahdi, all'epoca capo della polizia islamica del gruppo Ansar Dine affiliato ad Al Qaida. ${ }^{17}$ In tale ipotesi però, anche al fine di scongiurare comportamenti opportunistici da parte di soggetti non adeguatamente legittimati o non sufficientemente meritevoli, ${ }^{18}$ le vittime "enti morali" devono aver subìto un direct harm, il cui onere della prova grava su di esse, sia quanto a sussistenza del pregiudizio in sè, sia relativamente al nesso causale fra siffatto pregiudizio e il crimine da cui esso deriva. ${ }^{19}$

\section{Le ragioni sottese all'inclusione delle vittime nel procedimento dinanzi alla Corte penale internazionale}

Gli impulsi che hanno portato all'innovativa inclusione delle vittime nell'articolato sistema della CPI, facendole uscire da dietro le quinte, dove fino ad allora erano state confinate, sono molteplici e di variegata natura. La panoplia delle ragioni contempla inter alia fattori storici, teorie giuridiche, motivi pragmatici.

Sotto il primo profilo va ricordato, alla luce dei lavori preparatori dello Statuto, il contributo sia della cd società civile (in specie gruppi umanitari e organizzazioni non governative), ${ }^{20}$ sia di alcuni Stati (quali in particolare Regno Unito, ${ }^{21}$ Giappone $^{22}$ e Francia ${ }^{23}$ ) che ha spinto affinché l'istituenda Corte si conformasse a un sistema ibrido partecipativo-riparatorio. ${ }^{24}$

14 Le Rules of Procedure and Evidence dell'ICTY e dell'ICTR escludono le vittime indirette: ai sensi della Rule 2.a di entrambe le RPE, è considerata vittima esclusivamente "[...] a person against whom a crime over which the Tribunal has jurisdiction has allegedly been committed".

15 Inter alia cfr. Decision on Victims' Participation, in the case of The Prosecutor v. Thomas Lubanga Dyilo: "In relation to the link between the harm allegedly suffered and the crime, whereas Rule 85(b) of the Rules provides that legal persons must have "sustained direct harm", Rule 85(a) of the Rules does not include that stipulation for natural persons, and applying a purposive interpretation, it follows that people can be the direct or indirect victims of a crime within the jurisdiction of the Court". (ICC-01/04-01/06-1119, §91). Sul punto, la posizione adottata dalla Trial Chamber I è stata confermata dalla Camera d'appello, secondo la quale "[...] the harm suffered by a natural person is harm to that person, i.e. personal harm. Material, physical, and psychological harm are all forms of harm that fall within the rule if they are suffered personally by the victim. Harm suffered by one victim as a result of the commission of a crime within the jurisdiction of the Court can give rise to harm suffered by other victims [...] It is in this sense that the Appeals Chamber understands the Trial Chamber's statement that "people can be the direct or indirect victims of a crime within the jurisdiction of the Court". The issue for determination is whether the harm suffered is personal to the individual. If itis, it can attach to both direct and indirect victims. [...So,] the notion of victim necessarily implies the existence of personal harm but does not necessarily imply the existence of direct harm". (ICC-01/04-01/06-1432, Decision on the appeals of The Prosecutor and The Defence against Trial Chamber I's Decision on Victims' Participation of 18 January 2008, in the case of The Prosecutor v. Thomas Lubanga Dyilo, AC, 11 luglio 2008, § 32, 38)

16 L'art. 8.2.b.ix ed .e.iv dello Statuto della CPI indica come crimini di guerra, rispettivamente nei conflitti armati internazionali e interni, la condotta consistente in: "Intentionally directing attacks against buildings dedicated to religion, education, art, science or charitable purposes, historic monuments, hospitals and places where the sick and wounded are collected, provided they are not military objectives".

ICC-01/12-01/15-171, 27 September 2016, Trial Chamber VIII, Judgment. Cfr. Scovazzi (2017).

18 Non è possibile dar conto in questo breve contributo della problematica delle cd vittime non meritevoli, ossia circa l'opportunità di riconoscere o meno ad alcuni soggetti un locus standi innanzi alla CPI perché ad esempio al contempo vittime e perpetratori di crimini rientranti ratione materiae nella competenza della Corte, oppure perché in condizioni socio-economiche particolarmente agiate, sì da non necessitare della riparazione monetaria, ovvero perché vittime che hanno tratto in qualsivoglia maniera un vantaggio ingiustificato dal pregiudizio subito. Su questo tema si rinvia a Vilmer (2009, p. 35 ss.).

19 Per le difficoltà concrete che da questo "doppio binario" fra vittime-persone fisiche e vittime-enti morali comporta quanto al diritto di partecipare al procedimento, soprattutto alla luce della particolarità del sistema in causa (ossia che, pur trattandosi di una corte penale, la CPI si occupa non solo di casi, ma anche di situazioni) si veda Lattanzi (2010, p. 125 ss).

20 Per una ricostruzione del contributo fattivo delle ONG, come, in particolare la Croce Rossa e Human Rights Watch si veda <http://www.coalitionfortheicc. org>.

1 La proposta del Regno Unito si trova nel documento A/AC.2497/1997/WG.4/DP.13 del 10 dicembre 1997.

22 La proposta del Giappone si legge nel documento, A/CONF.183/C.1/WGPM/L.30 presentato alla Conferenza Diplomatica del 28 giugno 1998.

23 La delegazione francese aveva formulato una prima proposta (A/AC.249/1997/WG 4/DP.3) fin dai lavori del cd PrepCom nella sessione dell'agosto 1997. II 10 febbraio 1998 Francia e Regno Unito hanno coagulato i loro sforzi e hanno presentato una proposta congiunta (A/AC.249/1998/WG.4/DP.19).

24 Come efficacemente affermato "the "law of the Court" constitutes a new system of rules permitting the effective functioning of the machinery of international justice. Of course, this system may be considered as the "melting-pot" of some of the most adequate tendencies of criminal procedures stemming from all families of legal systems, forming thus a "highest common denominator" attainable by all legal models": (DONAT-CATTIN, 1999, p. 1275). Per un'analitica ricostruzione dei lavori preparatori dello Statuto della CPI cfr. Lee, 1999. Secondo taluno "the inherent tension between the diversified goals that the Court is willing to achieve is ultimately reflected in the incoherence of some norms of the ICC Statute": in tal senso Damaska (2010). 
Sotto il secondo profilo, il riferimento imprescindibile è dato dall'emersione e diffusione della restorative justice, attraverso l'elaborazione teorica in contesti nazionali, sovra-nazionali e internazionali, soprattutto nella prassi sempre più diffusa delle Commissioni di verità e pace, che sposta il cardine dell'anelito di giustizia da quello meramente retributivo a quello riparativo (CLAMP, 2016; HOLM, 2017). La restorative justice calza, per così dire, le lenti della vittima e postula che il ristabilimento dell'equilibrio violato dal crimine attraverso la riconciliazione e la riparazione possa avere un valore (terapeutico, giuridico, simbolico, culturale) pari, se non addirittura superiore, alla mera irrogazione di sanzioni penali afflittive a carico del responsabile delle violazioni (GARBETT, 2017). II sistema che ne deriva quindi fa un sapiente uso combinato di strumenti punitivi, mediativi e riparatori, finalizzati alla ricostruzione del tessuto sociale e comunitario lacerato dal crimine (STAHN, 2015).

Infine, sotto il terzo profilo la competenza della CPI non si sostituisce né si sovrappone a quella dei tribunali nazionali, poiché si attiva in funzione del principio di complementarità, in base al quale un caso non può essere giudicato (ossia è irricevibile) qualora lo Stato che ha giurisdizione stia svolgendo indagini al riguardo o stia esercitando l'azione penale, oppure abbia già svolto indagini e deciso di non perseguire le persone coinvolte. Viceversa il caso è ricevibile se nessuno Stato abbia iniziato le indagini (inaction scenario), ovvero se lo Stato competente non voglia (unwilling) o non possa (unable) svolgere indagini o esercitare correttamente l'azione penale (BURKE-WHITE, 2008). Poiché quindi la CPI esercita la sua competenza quale extrema ratio rispetto a un caso esclusivamente nell'ipotesi di mancata attivazione dei tribunali nazionali competenti, con il limite dell'irrilevanza dell'azione statale che non sia volta in buona fede e in modo corretto per un'efficace repressione del crimine (unica deroga al principio del ne bis in idem), non contemplare la possibilità di sanare il pregiudizio arrecato alle vittime di brutali crimini con una risposta ai loro bisogni concreti attraverso l'enucleazione di un apparato di meccanismi rimediali, avrebbe reso la CPI un sistema monco e incompiuto. Detto in altri termini, il tradizionale funzionamento della giustizia penale internazionale in virtù del quale il problema delle riparazioni è rinviato a (peraltro spesso inefficaci) meccanismi di diritto interno, suggerendo di fatto alle vittime di tentare la via del risarcimento dinanzi alle domestic Courts, non avrebbe avuto modo di ristorare efficacemente ed efficientemente le vittime proprio per il presupposto di partenza: l'incapacità o la mancanza di volontà dello Stato competente in prima battuta a occuparsi del crimine de quo.

\section{La triplice articolazione dei diritti delle vittime nello Statuto della Corte penale internazionale: alla partecipazione, alla riparazione, alla protezione}

II complesso e articolato sistema istituito dalla CPI riconosce alle vittime uno status del tutto innovativo nella storia del diritto penale internazionale, definito da taluno sui generis (LATTANZI, 2010, p. 137) che si dipana lungo tre traiettorie: partecipazione, riparazione, protezione. L'esatta ricostruzione di tale prisma giuridico emerge dall'intreccio delle norme contemplate nello Statuto, nel Regolamento di Procedura e Prova (Rules of Procedure and Evidence - RPE), nel Regolamento Interno della Corte (Regulations of the Court - RC) e nel Regolamento del Fondo Fiduciario per le Vittime (Trust Fund for Victims - TFV).

Sotto il primo profilo, per diritto alla partecipazione si intende la possibilità che le vittime dei crimini di competenza della Corte (i cd core crimes: genocidio, crimini contro l'umanità, crimini di guerra, aggressione) siano autorizzate - a seguito di una puntuale domanda scritta di ammissione, recapitata alla Cancelleria e da qui fatta circolare all'accusa e alla difesa, che potranno presentare osservazioni dalla camera giurisdizionale incaricata del caso specifico, ${ }^{25}$ a prendere parte al procedimento penale, nella

25 Si ritiene infatti del tutto corretta la posizione di chi ritiene (LATTANZI, 2010, p. 130 ss.) che, benché le vittime abbiano un interesse "di fatto" a partecipare a qualsiasi procedura davanti alla Corte, fin dalla fase in cui il Prosecutor esamina preliminarmente le notitiae criminis a lui pervenute ai fini di un'eventuale azione motu proprio, le vittime avendo interesse a che l'esame preliminare abbia un seguito nelle indagini volte a identificare dei possibili responsabili da sottoporre al giudizio della Corte, purtuttavia da tale interesse non discende purtroppo un diritto generale con riguardo a qualsiasi attività si svolga davanti alla Corte. In effetti il processo decisionale del Prosecutor circa la base ragionevole ("seriousness") della notitia criminis non è sottoposto a alcun vaglio giudiziario ulteriore, posto che questi ne è unico ed esclusivo dominus: di tal guisa in questa fase le vittime potranno solamente rivolgere le loro istanze al Prosecutor ma non partecipare al suo esame preliminare, non godendo le vittime - in questo stadio - di una posizione giuridicamente e normativamente riconosciuta e tutelata. $E$ poiché, giova ribadirlo, si è operata la scelta (più politica che giuridica, in verità) di non consentire alla Camera preliminare il potere di rivedere una decisione negativa del Prosecutor circa la fondatezza di una notitia criminis, procedimento nel cui àmbito le vittime ben avrebbero potuto intervenire, queste risultano del tutto escluse da questa fase. 
fase del giudizio ritenuta appropriata dalla Corte e in modo non pregiudizievole per il diritto dell'accusato/ imputato a un fair trial (su questo punto si veda in particolare ZAPPALÀ, 2010). La base giuridica di tale legittimazione processuale (nell'àmbito del procedimento penale strettamente inteso) è rinvenibile nell'art. 68.3 dello Statuto, laddove i suoi contenuti specifici, ossia i concreti atti di rilievo processuale consentiti alle vittime e ai loro rappresentanti in giudizio, sono genericamente disciplinati dalle Rules 89-93 del RPE. L'art. 68,3 recita:

\begin{abstract}
Where the personal interests of the victims are affected, the Court shall permit their views and concerns to be presented and considered at stages of the proceedings determined to be appropriate by the Court and in a manner which is not prejudicial to or inconsistent with the rights of the accused and a fair and impartial trial. Such views and concerns may be presented by the legal representative of the victims where the Court considers it appropriate, in accordance with the Rules of Procedure and Evidence.
\end{abstract}

Da un'analisi dell'art. 68.3 emerge che la concretizzazione del diritto delle vittime a partecipare al procedimento de quo va rinvenuto entro un perimetro costituito da quattro segmenti. In primo luogo, la Corte è obbligata (shall permit) a consentire alle vittime, su cui grava l'onere di provare il proprio interesse, la partecipazione al procedimento. Alla luce però del secondo elemento, quest'obbligo è temperato dalla discrezionalità della Corte sia tout court, sia quanto alla fase in cui consentire la partecipazione delle vittime, che è tenuta a motivare, in caso di diniego, la ratio excludendi. Ancora, una terza condizione che dev'essere rispettata è data dal fatto che la decisione della Corte dev'essere da questa adottata alla luce del giusto bilanciamento fra due interessi (potenzialmente) contrapposti: quello delle vittime a partecipare e quello dei diritti dell'accusato. Infine, la partecipazione delle vittime si concretizza nella possibilità di presentare alla Corte le proprie opinioni e preoccupazioni (views/concerns).

Dal combinato disposto delle disposizioni statutarie, del RC e del RPE si evince quindi che le vittime, se la CPI le autorizza, possono presentare osservazioni e avere accesso a informazioni riservate, ${ }^{26}$ secondo modalità non pregiudizievoli o incompatibili con i diritti dell'imputato e con l'imparzialità del processo. II rappresentante legale delle vittime, autorizzato dal giudice, può porre domande a testimoni, periti e imputati, nonché produrre documenti. ${ }^{27}$ Occorre sottolineare che la possibilità di partecipare al procedimento nasce fin dalla fase in cui la Camera preliminare esamina la richiesta motu proprio del Prosecutor di aprire le indagini ex art.19.3 dello Statuto: posto che la Rule 50 impone al Prosecutor di informare le vittime, queste sono individuate/individuabili sulla base di elementi desumibili dalla notitia criminis, dalla Victims and Witnesses Unit, dai rappresentanti legali delle vittime, ovvero attraverso altri canali, quali le informazioni fornite da Stati, da organi delle Nazioni Unite, da organizzazioni internazionali, governative e non, e da tutte le fonti esaminate dal Prosecutor durante l'esame preliminare ritenute attendibili. In tale ipotesi, la vittima, che non è tenuta a dimostrare il proprio interesse in quanto indubbiamente in re ipsa, può presentare representations. A fortiori tale inclusione è disposta nell'ipotesi di referral di uno Stato ex art.14: ai sensi dell'art.15.3 relativo a questo scenario è riconosciuto alla vittima il diritto di sottomettere alla Corte observations. L'art.75 dello Statuto stabilisce poi lo specifico diritto delle vittime di partecipare al distinto procedimento di riparazione (di natura amministrativa) in cui non sussiste invece alcun limite per le vittime e i loro rappresentanti quanto al loro poter prendere parte a siffatte udienze postdibattimentali penali. Da questo impianto si desume che le vittime non hanno un diritto al processo penale, dato che a esse è riconosciuta solamente la possibilità di segnalare al Prosecutor la commissione di crimini/situazioni rientranti nella giurisdizione della $\mathrm{CPI}$, essendo loro preclusa la possibilità di un'iniziativa diretta dell'attivazione del procedimento, laddove, viceversa, le vittime hanno un vero e proprio diritto al diritto al processo di riparazione tout court. Questo

26 Per esempio nel recente caso The Prosecutor v. Jean-Pierre Bemba Gombo "victims were authorised to participate at hearings and status conferences, to make opening and closing statements, to file written submissions, to introduce evidence, to question witnesses subject to a discrete written application decided upon in advance by the Chamber, and to have access to confidential documents in the record": The Prosecutor v. Jean-Pierre Bemba Gombo,ICC-01/05-01/08. Judgment pursuant to Article 74 of the Statute, 21 March 2016 , para. 24.

27 La Rule 90 del RPP stabilisce le modalità della rappresentanza delle vittime in giudizio, che si attua per mezzo della nomina di un rappresentante legale, prescrivendo altresì che laddove la numerosità delle vittime lo renda consigliabile, per ragioni di economia processuale e per la migliore tutela degli interessi del gruppo, le vittime debbano dotarsi di una rappresentanza comune Peraltro per favorire tali processi di aggregazione, specie rispetto a gruppi di vittime che sovente sono prive di adeguati mezzi economici, è stata istituita, in base alla Rule 81 del Regolamento della Corte, la struttura di supporto alle vittime nota come Office of Public Counsel for Victims (OPCV). 
doppio binario di strumenti e poteri processuali si chiarisce alla luce della diversa qualifica che le vittime rivestono nel procedimento penale vero e proprio, ove assumono uno status, per così dire, di intervenienti (secondo taluno, in buona sostanza, un ibrido fra "a partie civile, a supplementary source of prosecution, and an amicus curiae": (MÉGRET, 2015); secondo altri "as an integral part of the ICC's synergy victims are independent actors in the ICC's arena, distinct from the parties and other non-party participants" (BACHVAROVA, 2017), rispetto al procedimento di riparazione. Infatti, in tale segmento procedimentale, le vittime assurgono al rango di vere e proprie parti, sullo stesso piano di accusa e difesa, con tutta la panoplia dei poteri processuali riconosciuta alle parti in senso stretto nei procedimenti davanti alla Corte (SCHABAS; MCDERMOTT; HAYES, 2016).

Sotto il secondo profilo, per diritto alla riparazione si intende la possibilità per le vittime di conseguire il ristoro del pregiudizio - subito in conseguenza della commissione, ai loro danni, di un crimine di competenza della Corte - sia stricto sensu, ossia mediante gli specifici ordini di riparazione che la CPI, eccezionalmente ex officio, di norma ex parte, emani ex art.75 dello Statuto a favore delle vittime di un crimine il cui responsabile sia stato sottoposto a giudizio e condannato, sia lato sensu, ossia quale supporto alle vittime, per tale intendendosi ogni attività, condotta dal TFV, che miri a fornire assistenza alle vittime durante e al di là del procedimento penale (e dei suoi esiti), ossia a prescindere dalla pronuncia di una sentenza di condanna e di appositi ordini di riparazione della Corte.

Base giuridica del diritto alla riparazione sono gli artt. 75 e 79 dello Statuto, le Rules 94-99 del RPP e le Rules 49-50 e 54-75 del RegTFV. Nella prima accezione, ossia come diritto alla riparazione in senso stretto, merita evidenziare come l'incisività della volontà della vittima abbia diversi gradi a seconda che la richiesta di riparazione parta da essa, ovvero sia disposta per iniziativa della Corte. Nel primo caso la vittima potrà giovarsi di un'application form, predisposta dalla Victims and Witnesses Unit da depositare in cancelleria, in cui, inter alia, potrà specificare l'ammontare della (eventuale) pretesa risarcitoria monetaria nonché ulteriori tipologie di misure rimediali (quali restitutio in integrum, riabilitazione, altre forme simboliche, come ad esempio la richiesta di scuse ufficiali). In questo caso, sebbene Corte non sia vincolata alla richiesta specificamente avanzata dalle vittime in ordine a entità e tipo di misure di riparazione, purtuttavia le indicazioni della vittima possono costituire una linea guida che aiuti i giudici, preso atto dei desiderata della vittima, a scegliere le misure che possano essere apprezzate al meglio, tenuto conto del contesto di vittimizzazione, nel pieno rispetto delle diverse culture. Nella seconda ipotesi, ossia se la Corte decide motu proprio di procedere a riparazioni a prescindere quindi da un'esplicita domanda proveniente dai soggetti interessati e potenzialmente legittimati a richiedere la riparazione, la volontà della vittima, cui tale intenzione deve essere notificata per accettazione, prevale.

In particolare si profilano tre scenari: nel primo, la vittima si dichiarerà concorde con l'iniziativa, sicché si procederà secondo l'intenzione della Corte; nel secondo, la vittima porrà in essere una sua propria richiesta ex Rule 94; nel terzo, la vittima manifesterà il suo dissenso. Ebbene in questa terza ipotesi la volontà contraria della vittima è ostativa e preclusiva per la Corte. Questa eventualità non è meramente scolastica: basti pensare a casi di stupro nei quali spesso la vittima viene stigmatizzata e esiliata dal gruppo sociale di appartenenza, sicché imporre autoritativamente dall'alto misure riparatorie, attesa la relatività dei valori in materia di giustizia e riparazione, potrebbe in taluni casi produrre una seconda vittimizzazione (su questi aspetti si veda SACOUTO, 2012).

Sempre nel quadro del diritto delle vittime alla riparazione, occorre sottolineare l'originalità dell'istituzione del TFV, per così dire, braccio operativo della CPI, posto che è a esso che i concreti ordini di riparazione della Corte sono rivolti. Come caso di prassi sembra utile riferirsi all'ordine di riparazione del 17 Agosto 2017 emesso dalla Trial Chamber VIII della CPI nel caso Ahmad Al Faqui Al-Mahdi, condannato dalla stessa Camera con sentenza del 27 settembre 2016 per la violazione dell'art.8.2.e.iv, che, come già ricordato, qualifica quale crimine di guerra l'attacco intenzionale nell'àmbito di un conflitto armato di carattere non-internazionale nei confronti di edifici dedicati al culto, all'educazione, all'arte, alla scienza o a scopi umanitari, monumenti storici, ospedali e luoghi di raccolta di malati e feriti, ove tali luoghi non siano impiegati con finalità militari. In tale ordine di riparazione, la Corte ha dettato le guidelines per la riparazione 
collettiva, riconoscendo ai componenti della comunità maliana largamente intesa un obbligo di riparazione simbolico di un euro ciascuno, e invitando a concentrarsi più nello specifico sulla comunità di Timbuktu, direttamente colpita dagli effetti del crimine rispetto alla deminutio degli introiti derivanti dal turismo di tale città: siffatta limitazione sottolinea la natura prettamente riparatoria dell'ordine in esame volta a scongiurare il rischio che la riparazione si trasformi in un aiuto umanitario (cfr. GOVERNA, 2017).

Ebbene, spetterà ora al TFV proporre un piano, strutturato sulle linee guida dettate dalla Camera, che dovrá poi essere approvato: di tal guisa si conferma quanto già affermato nella giurisprudenza dell'Appeals Chamber che, nel caso Lubanga Dyilo (ICC-01/04-01/06-3129) aveva riconosciuto la piena autonomia del TFV e l'impossibilità per la Camera di obbligare il Fondo all'esecuzione dell'ordine di riparazione. II TFV ha un ulteriore ruolo nel caso di insolvenza (totale o parziale) del condannato, poiché assume la veste di organo che dovrebbe essere in grado di ristorare economicamente le vittime, sopperendo all'incapacità contributiva del condannato, attraverso le risorse del fondo costituite da risorse proprie (provenienti da contributi degli Stati Parte, sanzioni pecuniarie e confische) e le risorse, provenienti dal condannato, che gli vengono trasferite ex Rule 98.2 del RPE. ${ }^{28}$ Detto in altri termini il TFV ha un ruolo bicefalo di attuazione e implementazione, poiché è al contempo tesoriere di fondi e intermediario tra perpetratore e vittime, nonché collettore di risorse aggiuntive o suppletive nel caso di carenza o assenza di mezzi in capo al condannato personalmente obbligato. A tali due compiti si aggiunge poi quello di "anello di congiunzione" con ulteriori soggetti decentrati (quali organizzazioni nazionali e internazionali, governative e non, più vicine al contesto nel deve intervenire la riparazione) cui affidare l'esecuzione delle riparazioni. Infatti, è altresì previsto che la Corte, d'intesa con gli Stati interessati e il TFV, possa stabilire che le risorse del Fondo siano trasferite a siffatte organizzazioni (intergovernative o non governative), internazionali o nazionali approvate dal TFV, delegando loro il compito, in ragione della loro maggiore vicinanza alle vittime, di attuare concretamente le riparazioni in base all'apprezzamento delle specifiche necessità delle vittime. La ratio sottesa è che, data la maggiore consapevolezza e conoscenza di tali organizzazioni delle necessità concrete delle vittime, le misure adottate attraverso la gestione delle risorse a disposizione saranno più appropriate, con minor repentaglio sia di effetti collaterali negativi, sia quale antidoto al rischio di un'imposizione di certi valori propri dell'identità culturale occidentale, alla luce di un errato universalismo dei presupposti assiologici (sui profili critici di questa attuazione "doppiamente decentrata" del diritto alla riparazione cfr. McCarthy (2012, p. 276 ss.).

Infine, sotto il terzo profilo per diritto alla protezione si intende la possibilità che la Corte emani, motu proprio o su richiesta del Prosecutor o degli interessati, ogni disposizione necessaria a garantire la sicurezza, l'incolumità psico-fisica, la dignità e la privacy delle vittime (e dei testimoni) durante tutto lo svolgimento del procedimento, ancor prima dell'inizio del processo penale strettamente inteso e successivamente a esso. Le norme che disciplinano tale diritto, volto a evitare che la vittima possa subire ulteriore pregiudizio per effetto delle vicende processuali che la coinvolgono, si rinvengono nell'art.68 Statuto e, più dettagliatamente nelle Rules 87-88 del RPE.

\section{Conclusioni}

La ricostruzione normativa del ruolo della vittima nell'articolato sistema istituzional-procedimentale della CPI ci consente di tracciare delle brevi osservazioni conclusive. Sotto un coté positivo, va sicuramente apprezzato l'upgrading che in questo contesto è riconosciuto alle vittime dei cd core crimes di competenza ratione materiae della Corte, poiché, come si è cercato di evidenziare, l'apparato normativo della Corte cerca di assegnare un ruolo non più marginale alle vittime, ma le fa assurgere al rango di protagoniste, riconoscendo loro una posizione giuridica soggettiva ad attuazione giurisdizionale.

\footnotetext{
28 II TFV è stato istituito il 9 settembre 2002 attraverso la Risoluzione ICC-ASP/1/Res.6 adottata per consensus dall'Assemblea degli Stati Parte. L'adozione del Regolamento del TFV è avvenuta il 3 dicembre 2005 con la Risoluzione ICC-ASP/4/Res.3 anch'essa adottata per consensus dall'Assemblea degli Stati Parte.
} 
Non bisogna peraltro sottacere alcuni profili critici che emergono da un'attenta analisi delle regole materiali e processuali (MOFFETT, 2015). In primo luogo, emerge un problema definitorio delle vittime nel contesto processuale dal punto di vista qualitativo e temporale. In effetti, come si è cercato di evidenziare nel paragrafo precedente, la connotazione bicefala del meccanismo riparatorio presenta commistioni che rendono difficile individuare l'esatta natura del ruolo delle vittime nel processo penale strettamente inteso, e dunque delle prerogative processuali a loro disposizione, sia per quel che concerne la loro qualificazione, sia dal punto di vista del loro poter partecipare al processo solamente se a ciò espressamente autorizzate dalla Camera. In effetti, nel momento in cui la Corte vaglia le richieste di autorizzazione a partecipare al processo penale, pone in essere una delicata valutazione circa la sussistenza della qualità di vittima e dell'interesse personale a intervenire: ebbene, ciò può comportare degli indesiderati effetti negativi per eccesso ovvero per difetto di tale qualificazione. Infatti, da un lato, laddove dette valutazioni siano positive, fondandosi sulla supposizione che, prima facie, vi siano ragioni di credere che il crimine contestato si sia effettivamente consumato e sia attribuibile all'accusato/imputato, la convalida giudiziale dello status di vittima, precedendo la determinazione giudiziale sul fatto di rilevanza penale e sulla colpevolezza dell'imputato, suscita preoccupazione quanto alla possibilità che ciò violi la fondamentale presunzione d'innocenza stabilita ex art.66.1 dello Statuto e quindi, di fatto, un fair trial. Dall'altro, viceversa, il mancato riconoscimento di un locus standi alle vittime, potrebbe compromettere, più o meno irreparabilmente, la loro possibilità di vedersi riconosciuto, anche col giudizio di riparazione ex post, una serie di diritti e garanzie. II tutto tenendo conto di un'altra difficoltà in re ipsa ossia la conformazione del diritto alla riparazione, costruito come un diritto personale e individuale della vittima legittimata a farlo valere in giudizio. In effetti, sebbene le vittime possano giovarsi di una rappresentanza processuale comune, la configurazione marcatamente individualistica mal si adatta alla natura specifica dei crimini di competenza della Corte, di carattere quasi per definizione massivo, con pluralità di perpetratori e di vittime. Basti pensare che nel caso The Prosecutor v. Jean-Pierre Bemba Gombo, la CPI ha riconosciuto 5.229 vittime per le violenze commesse tra il 26 ottobre 2002 e il 15 marzo 2003 nella Repubblica Centrafricana dai 1.500 uomini della milizia Movimento di liberazione del Congo fondata da Jean-Pierre Bemba, la maggior parte delle quali sono donne che hanno subito violenze sessuali (ICC-01/05-01/08).

Questo primo profilo critico si riverbera inevitabilmente a cascata anche su un altro piano, per così dire, empirico: vero è che, come già ricordato, lo Statuto e il RPE prevedono la possibilità per le vittime di coagulare i loro sforzi volti a far sentire la loro voce e a ottenere una riparazione attraverso varie previsioni ad hoc (inter alia, possibilità di nominare un unico legale, applications standardizzate, servizi dell'OPCV per coadiuvare i rappresentanti legali delle vittime) ma di fatto ciò presuppone non solamente una concreta conoscenza delle vittime dello svolgimento del procedimento davanti alla CPI, ma anche una parità di mezzi (economici, culturali, etc.) idonei a far valere con efficacia il proprio diritto alla riparazione, mezzi di cui, di fatto, le vittime, per ragioni personali o patrimoniali, non sono egualmente dotate (su questi profili cfr. ZAGO, 2014).

Ancora un altro problema è relativo al TFV, poiché, in effetti, in caso di insolvenza del condannato, il sistema della CPI non offre una garanzia assoluta alle vittime di ottenere concretamente riparazione perché non è contemplata prevista alcuna forma di responsabilità sussidiaria o solidale in capo agli Stati, sicché tale organo, potenzialmente idoneo a sopperire all'incapienza economica del condannato, non può contare su alcun meccanismo sicuro, stabile e prevedibile di finanziamento, dipendendo, in larga misura, da aleatorie e incerte contribuzioni volontarie di Stati o privati (VILMER, 2009, p. 46 ss.).

Un'ulteriore criticità che emerge è data dalla consapevolezza che, sebbene in punto di diritto il procedimento penale in senso stretto e il procedimento di riparazione siano strutturati a compartimenti stagni, purtuttavia il secondo si pone pragmaticamente su un continuum logico-temporale, rappresentando di una naturale prosecuzione del procedimento penale sfociato in una sentenza di condanna, posto che la fase delle procedure riparatorie può aprirsi tecnicamente solo in esito a tale condanna in sede giudiziale: se si considera poi che l'attuazione concreta degli ordini di riparazione può materialmente intervenire, in caso di impugnazione della sentenza di condanna, esclusivamente quando la pronuncia medesima sia divenuta 
res iudicata definitiva, è di palmare evidenza come possa allargarsi a dismisura lo iato temporale fra il momento in cui la vittima ha subìto la lesione dei suoi diritti e il conseguimento concreto della riparazione.

Tali limiti non devono peraltro smorzare l'entusiasmo suscitato dalla CPI, piuttosto devono essere di stimolo affinché la Corte e l'Assemblea degli Stati Parte dello Statuto trovino gli strumenti che possano sopperire a tali criticità aiutando le vittime a ritrovare la propria voce, non spezzando più la loro sintassi, nel pieno rispetto del diritto alla verità e alla memoria, posto che le vittime sono la vera e propria raison d'être della giustizia penale internazionale.

\section{Riferenze}

AMATI, E. et al. (Ed.). Introduzione al diritto penale internazionale. 3. ed. Torino: Giappichelli, 2016. ANZILOTTI, D. La responsabilité internationale des Etats à raison des dommages soufferts par les étrangers. Revue Générale de Droit International Public, Paris, v.13, n. 1, p. 5-29 et 285-309,1906.

BACHVAROVA, T. The standing of victims in the procedural design of the International Criminal Court. Leiden: Brill Nijhoff, 2017.

BARIL, M. et al. Mais nous les témoins. Une étude exploratoire des besoins des témoins au Palais de justice de Montréal. Montreal: Centre international de criminologie comparée, Université de Montréal, 1985.

BASSIOUNI, M. C. International recognition of victims' rights. Human Rights Law Review, Oxford, v. 6, n. 2, p. 203-279, 2006.

BURKE-WHITE, W. Proactive complementarity: The International Criminal Court and National Courts in the Rome System of International Justice. Harvard International Law Journal, Cambridge, v. 49, n.1, p. 53-108, 2008.

CLAMP, K. (Ed.). Restorative justice in transitional settings. London: Routledge, 2016.

DAMASKA, M. Problematic features of international criminal procedure. In: CASSESE, A. The Oxford Companion to International Criminal Justice. Oxford: Oxford University Press, 2010. p. 175-186.

DEL PILAR MARTÍN RÍOS, M. Víctima y justicia penal: reparación, intervención y protección de la víctima en el proceso penal. Barcelona: Atelier Libros, 2012.

DONAT - CATTIN, D. Protection of Victims and Witnesses and their Participation in the Proceedings. In: TRIFFTERER, O. (Ed.). Commentary on the Rome Statute of the International Criminal Court: observers notes, article by article. 2. ed. München: Beck, 2008. p. 1275-1300.

GARBETT, C. The International Criminal Court and restorative justice: Victims, Participation and the processes of justice. Restorative Justice, Oxfordshire, v. 5, n. 2, p. 198-220, 2017.

GOVERNA, J. II caso Al-Mahdi innanzi alla Corte Penale Internazionale: la sentenza di condanna e l'ordine di riparazione. Giurisprudenza Penale, Milano, Fascicolo 9, 2017.

GREENWOOD, C. International Humanitarian Law (Laws of War). In: KALSHOVEN, F. (Ed.). The Centennial of the First International Peace Conference, p. 161-259. The Hague: Kluwer Law International, 2000.

HOLM, F. Justice for victims of atrocity crimes prosecution and reparations under international law. Umeå (Sweden): UmU Tryckservice, 2017.

KALSHOVEN, F. State responsibility for war like acts of the armed force: from Article of the Hague Convention IV of 1907 to article 91 of Additional Protocol I of 1977 and Beyond. International and Comparative Law Quarterly, Cambridge, v. 40, n. 4, p. 827-858, 1991.

LATTANZI, F. La partecipazione delle vittime alle procedure davanti alla Corte penale internazionale. In: AA.VV. Processo penale e vittima di reato. Prospettive internazionali, europee e nazionali. Centro di documentazione europea, Università di Catania - Online Working Paper, p. 123-138, 2010. 
LEE, R. S. (Ed.) The International Criminal Court: the making of the Rome statute, issues, negotiations, results. The Hague: Kluwer Law International, 1999.

MCCARTHY, C. Reparations and victim support in the International Criminal Court. Cambridge: Cambridge University Press, 2012.

MÉGRET, F. Victims before the International Criminal Court: a new model of criminal justice? Victims of Crime Research Digest, Government of Canada, v. 5, p. 23-27, 2013.

MOFFETT, L. Elaborating justice for victims at the international criminal court: Beyond Rhetoric and The Hague. Journal of International Criminal Justice, Oxford, v. 13, n. 2, p. 281-311, 2015.

$\mathrm{OCHI}, \mathrm{M}$. The international criminal court's reparation procedure in the lubanga case: The restorative justice's demand and the significance in international law. International Public Policy Studies, v. 20, n. 2, p. 31-46, 2016.

OLUGBUO, B. C.; WACHIRA, G. M. Enhancing the protection of the rights of victims of international crimes: A model for East Africa. African Human Rights Law Journal, Petroria, v. 11, n. 2, p. 608-638, 2011.

PERRAKIS, S. La réparation de victimes des violations du droit humanitaire et le droit individuel d'accès à la justice, état de lieu et perspectives d'avenir. In: ACCONCI, P. et al. (Ed.). International Law and the Protection of Humanity: Essays in Honor of Flavia Lattanzi. Leiden: Brill Nijhoff, 2017. p. 279-293.

SACOUTO, S. Victim Participation at the International Criminal Court and the Extraordinary Chambers in the Courts of Cambodia: A feminist project. Michigan Journal of Gender and Law, Michigan, v. 18, n. 2, p. 297-359, 2012.

SCHABAS, W.; MCDERMOTT, Y.; HAYES, N. (Ed.). The ashgate research companion to international criminal law: Critical perspectives. New York: Routledge, 2016.

SCOVAZZI, T. La prima sentenza della Corte penale internazionale in tema di distruzione di beni culturali. Diritti umani e diritto internazionale, Bologna, v. 1, p. 77-86, 2017.

STAHN, C. International criminal justice and reconciliation: Beyond the retributive v. restorative divide. Brussels: Torkel Opsahl Academic Epublisher, 2015.

VILMER, J.-B. Les réparations aux victimes devant la CPI. Paris: Presses universitaires de France, 2009.

WEMMERS, J. Victims' rights are human rights: The importance of recognizing victims as persons. Temida Journal, Serbia, v. 15, n. 2, p. 71-84, 2012.

ZAGO, G. The role of victims at the international criminal court: legal challenges from the tension between restorative and retributive justice. Diritto Penale Contemporaneo, Mllano, p. 1-17, 2014.

ZAPPALÀ, S. The rights of victims v. the rights of the accused. Journal of International Criminal Justice, Oxford, v. 8, n. 1, p. 137-164, 2010.

ZEGVELD, L. Remedies for victims of violations of international humanitarian law. International Review of the Red Cross, Geneva, v. 85, n. 851, p. 497-526, 2003.

\section{Autora convidada}

